
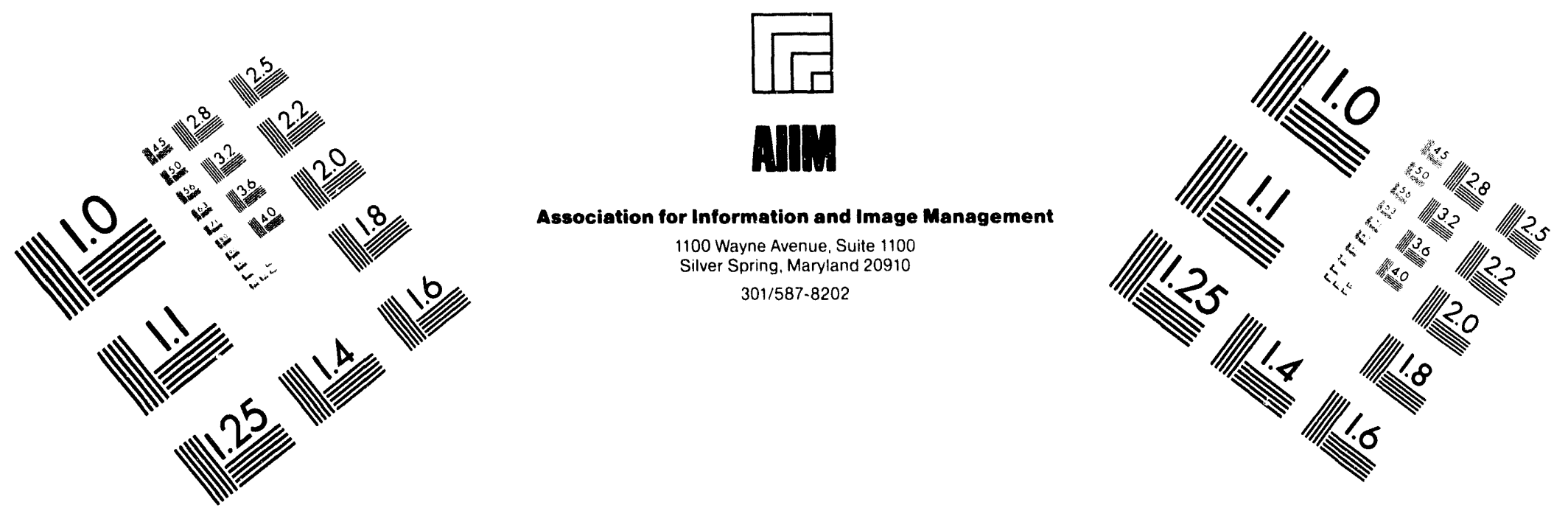

\title{
Centimeter
}

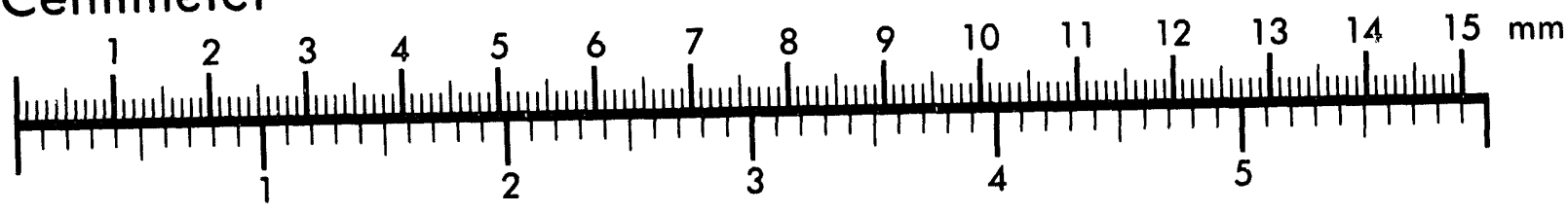
Inches
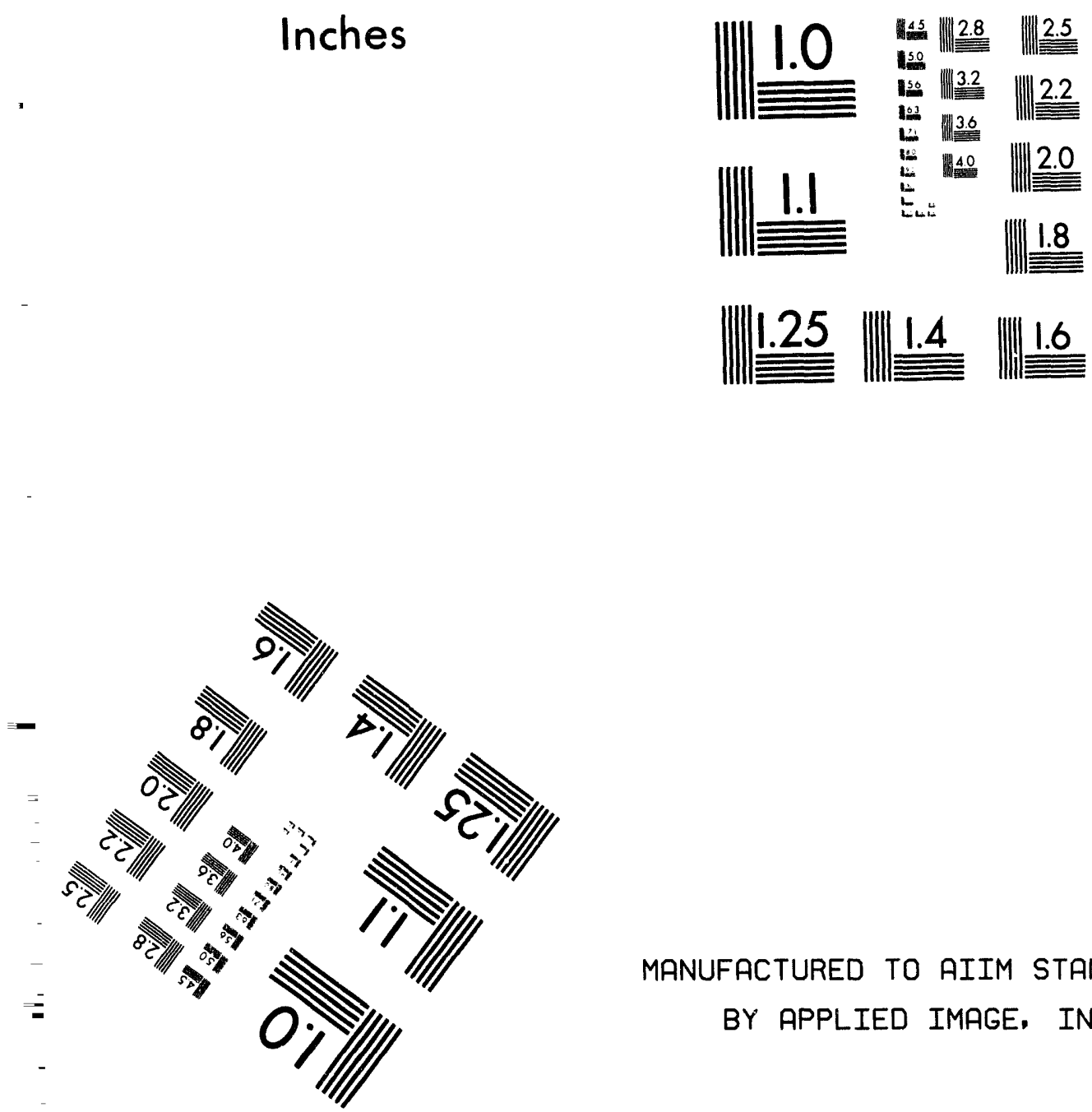

MANUFACTURED TO AIIM STANDARDS

BY APPLIED IMAGE, INC.

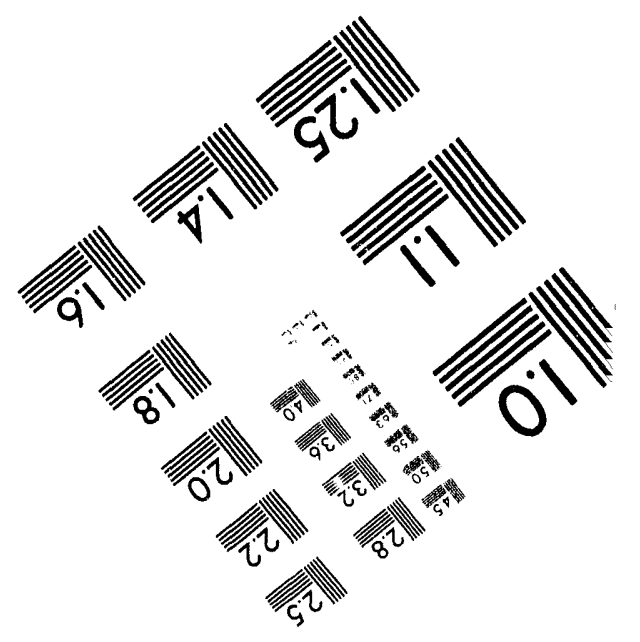



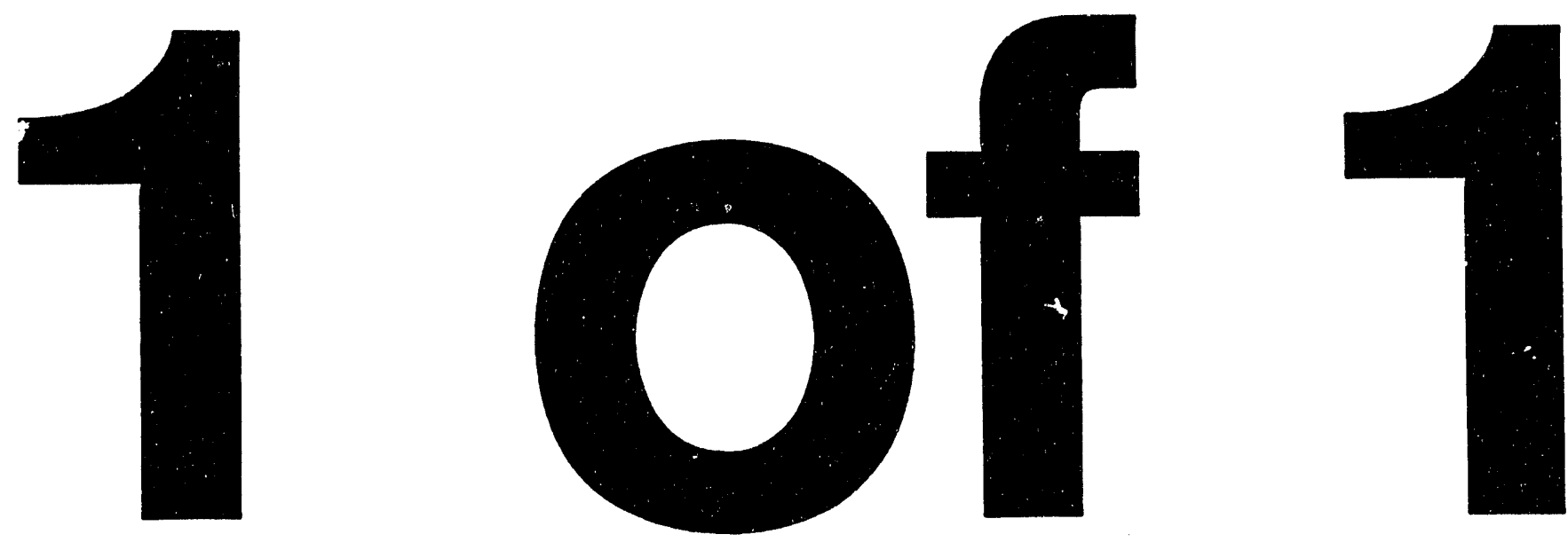


\section{Comprehensive Report to Congress Clean Coal Technology Program}

\section{Four Rivers Energy Modernization Project}

\section{A Project Proposed By: Air Products and Chemicals Inc.}

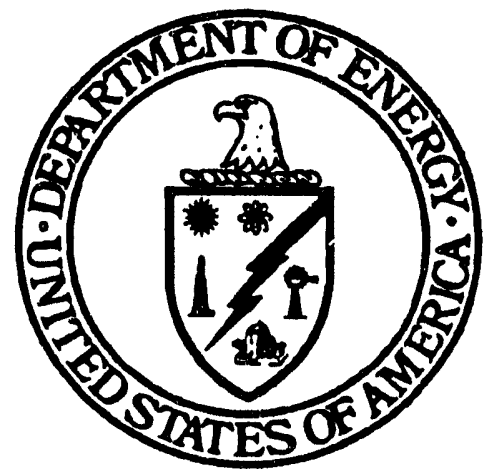

\section{U.S. Department of Energy Assistant Secretary for Fossil Energy Office ofCleanCoal Technology Washington, D.C. 20585}

June 1994 
TABLE OF CONTENTS

Page

1.0 EXECUTIVE SUMMARY $\ldots \ldots \ldots \ldots \ldots \ldots \ldots \ldots \ldots \ldots \ldots \ldots \ldots$

2.0 INTRODUCTION AND BACKGROUND $\ldots \ldots \ldots \ldots \ldots \ldots \ldots \ldots \ldots, 3$

2.1 Requirement for a Report to Congress ......... 3

2.2 Evaluation and Selection Process ............ 4

2.2 .1 PON Objective $\ldots \ldots \ldots \ldots \ldots \ldots \ldots \ldots \ldots, 4$

2.2.2 Qualification Review .............. 4

2.2.3 Preliminary Evaluation .............. 5

2.2.4 Comprehensive Evaluation $\ldots \ldots \ldots \ldots \ldots \ldots, 5$

2.2.5 Program Policy Factors .............. 5

2.2.6 Other Considerations ............... 6

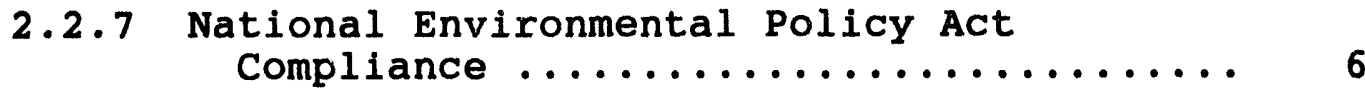

2.2 .8 Selection $\ldots \ldots \ldots \ldots \ldots \ldots \ldots \ldots \ldots \ldots, 6$

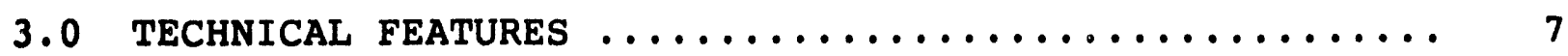

3.1 Project Description .................. 7

3.1 .1 Project Summary $\ldots \ldots \ldots \ldots \ldots \ldots \ldots \ldots \ldots, 10$

3.1.2 Project Sponsorship and Cost ........... 10

3.2 Second Generation PCFB Process .............. 11

3.2.1 Overview of Process Development ......... 11

3.2.2 Process Description ................ 12

3.3 General Features of Project .............. 13

3.3.1 Evaluation of Developmental Risk ....... 13

3.3.1.1 Similarity of Project to other

Demonstration and Commercial

3.3.1.2 Technical Feasibility............. 15

3.3.1.3 Resource Availability .......... 15

3.3.2 Relationship Between Project Size and

Projected Scale-Up of Commercial

Facility ....................... 15

3.3.3 Role of Project in Achieving Commercial

Feasibility of Technology .......... 16

3.3.4 Agreement with an Electric Utility ....... 17

4.0 ENVIRONMENTAL CONSIDERATIONS $\ldots \ldots \ldots \ldots \ldots \ldots \ldots \ldots \ldots$ 
TABLE OF CONTENTS

(Continued)

$\underline{\text { Page }}$

5.0 PROJECT MANAGEMENT ......................... 21

5.1 Overview of Management Organization .......... 21

5.2 Identification of Respective Roles

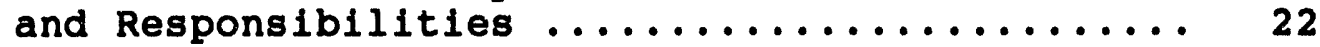

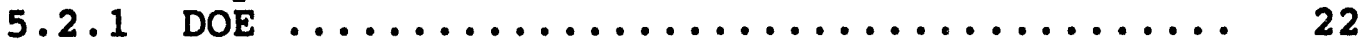

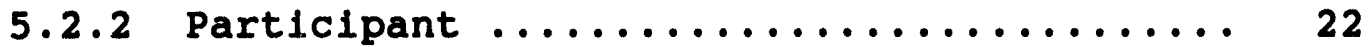

5.3 Project Implementation and Control Procedure .... 23

5.4 Key Agreements Impacting Data Rights, Patent Waivers, and Information Reporting .... 23

5.5 Procedures for Commercialization of Technology ......................... 24

6.0 PROJECT COST AND EVENT SCHEDULING ............... 24

6.1 Project Baseline Costs .................... 24

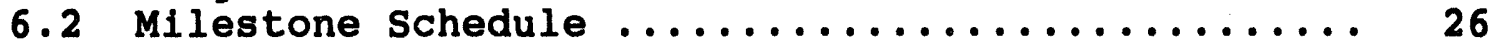

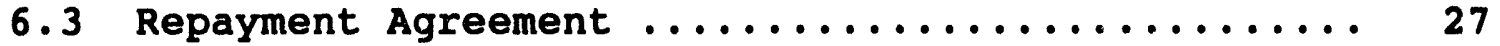




\subsection{EXECUTIVE SUMMARY}

Public Law 102-154 provided funds to the U.S. Department of Energy (DOE) to conduct cost-shared Clean Coal Technology (CCT) projects for the design, construction, and operation of facilities that "...shall advance significantly the efficiency and environmental performance of coal-using technologies and be applicable to either new or existing facilities...". This Act, together with Public Law 101-512, made available a total of $\$ 600$ million for a fifth general request for Proposals under the CCT program. To that end, a Program Opportunity Notice (PON) was issued by DOE in July 1992 .

In response to the PON, 24 proposals were received by DOE in December 1992. After evaluation, five projects were selected for award. These projects use technologies that significantly advance efficiency and environmental performance and are applicable to either new or existing facilities.

One of the five projects selected for funding is a project proposed by Air Products and Chemicals. Inc. (APCI) of Allentown, Pennsylvania. APCI requested financial assistance from DOE for the design, construction, and operation of a 95 megawatt-electric (MWe) gross equivalent, second generation, pressurized, circulating fluidized bed (PCFB) combustor cogeneration facility. The project, named the Four Rivers Energy Modernization Project, is co be located adjacent to an existing APCI chemicals manufacturing facility in Calvert City, Kentucky (Figure 1). Four Rivers Energy Partners, L.P. (FREP), will execute the project.

The demonstration plant will produce approximately 70 MWe for the utility grid and an average of 310,000 pounds per hour of process steam for the chemicals manufacturing facility. The project, including the demonstration phase, will last 80 months at a total cost of $\$ 360,707,500$. DOE's share of the project cost will be 39.5 percent, or $\$ 142,460,000$.

The objective of the proposed project is to demonstrate a second generation PCFB system based on technology being supplied by Foster Wheeler Energy Corporation (FWEC), Westinghouse Electric Corporation (Westinghouse), and LLB Lurgi Lentjes Babcock Energietechnik GmbH (LLB). The integrated performance to be demonstrated will involve all of the process systems, including coal preparation and feed, sorbent feed, carbonizer, char transfer, PCFB combustor, carbonizer and combustor hot-gas filtration, carbonizer and combustor alkali removal, topping combustor, gas turbine-generator, heat recovery steam generator (HRSG), steam turbine-generator, and balance-of-plant systems. The project will utilize Western Kentucky and southern Illinois bituminous coal. 


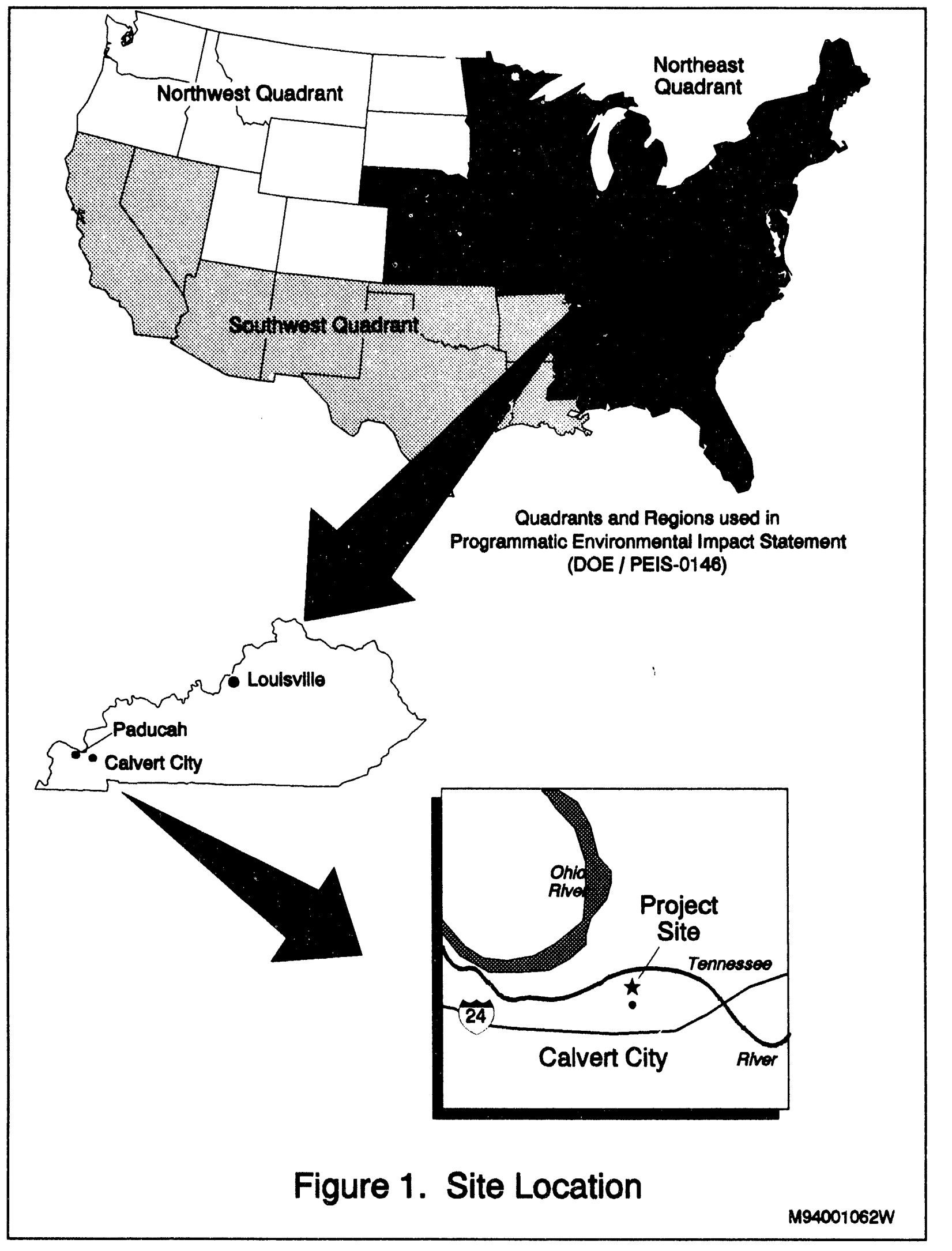


The Project will utilize technologies that, when integrated, are capable of achieving an efficiency of 45 percent and providing significant energy cost savings, while reducing emission levels as compared to conventional coal-fired boilers. The sulfur dioxide removal rate is expected to be greater than 95 percent, and the reduction rate for the oxides of nitrogen is expected to be greater than 75 percent. If the Project is as successful as anticipated, it will demonstrate that power plants based on this technology can be built at capital costs and thermal efficiencies which significantly reduce electric power costs over more conventional technologies.

Successful demonstration of the second generation PCFB technology will accelerate the application of this technology to existing and new facilities. Widespread deployment of this technology would significantly reduce emissions of acid precipitation precursors and carbon dioxide. The project team has committed to aggressively market the technology in both the United States and worldwide, expanding the market for domestic coal and power generation technologies.

The Four Rivers Energy Modernization Project is one of four pressurized fluidized bed combustion (PFBC) projects being demonstrated in the CCT Program. The Four Rivers Energy Modernization Project is unique in that it will be the first large-scale, fully-integrated second generation PCFB system.

\subsection{INTRODUCTION AND BACKGROUND}

\subsection{REQUIREMENT FOR A REPORT TO CONGRESS}

On November 13, 1991, Public Law 102-154, the Department of the Interior and Related Agencies Appropriations Act, 1992 (Act), was signed into law. This Act, among other things, provided funds to DOE to conduct cost-shared CCT Projects for design, construction, and operation of facilities that "...shall advance significantly the efficiency and environmental performance of coal-using technologies and be applicable to either new or existing facilities...". This Act directed DOE to issue the fifth solicitation of the CCT Program no later than July 6, 1992, and specified that selection of Projects for negotiations shall take place "...not later than ten months after the issuance date of the fifth general request for proposals."

The Act, together with Public Law 101-512, made available a total of $\$ 600$ miliion for the fifth general request for Proposals under the CCT Program. Of these monies, $\$ 7.2$ million were required to be reprogrammed for the Small Business and Innovative Research Program and $\$ 25.0$ million were designated as Program Direction funds for costs incurred by DOE for implementing of the CCT-V Program. All of the remaining appropriated funds, $\$ 567.8$ million, were available for award under the CCT-V PON. 
The purpose of this Comprehensive Report is to comply with Public Law 102-154 which directs the DOE to prepare a full and comprehensive report to Congress on each project selected for award under the CCT-V Program.

\subsection{EVALUATION AND SELECTION PROCESS}

DOE issued a draft PON for public comment on April 20, 1992, receiving a total of 42 responses from the public. The $f . n a l$ PON was issued on July 6, 1992, and took into consideration the public comments on the draft PON. On December 7, 1992, DOE received 24 proposals in response to the CCT-V solicitation. One proposal, which was received after the deadline date, did not qualify under any of the exceptions for late proposals specified in the PON and was, thereby, not considered in the evaluation process.

\subsubsection{PON Objective}

As stated in PON Section 1.2, the objective of the CCT-V solicitation was to obtain "proposals to conduct cost-shared Demonstration Projects that advance significantly the efficiency and environmental performance of coal using technologies and that are applicable to either new or existing facilities."

\subsubsection{Qualification Review}

The PON established seven Qualification Criteria and provided that, "In order to be considered in the Preliminary Evaluation Phase, a proposal must successfully pass Qualification." The Qualification Criteria were as follows:

(a) The proposed Demonstration Facility must be located in the United States.

(b) The proposed Demonstration Facility must be designed for and operated with coal. These coals must be from mines located in the United States.

(c) The Proposer must agree to provide a cost share of at least 50 percent of total allowable Project cost, with at least 50 percent in each of the Budget Periods.

(d) The Proposer must have access to, and use of, the proposed site of the Demonstration Facility and any proposed alternate site for the duration of the Demonstration Project.

(e) The proposed Project Team must be identified and firmly committed to fulfilling its proposed role in the Project. 
(f) The Proposer agrees that, if selected, it will submit a "Repayment Agreement" consistent with PON Section 7.7.

(g) The Proposal must be signed by a responsible official of the proposing organization authorized to contractually bind the organization to the performance of the Cooperative Agreement in its entirety.

\subsubsection{Preliminary Evaluation}

The PON provided that a Preliminary Evaluation would be performed on all proposals that successfully passed the Qualification Review. In order to be considered in the Comprehensive Evaluation phase, a proposal must be consistent with the stated objectives of the PON, and must contain sufficient finance, management, technical, cost, and other information to permit the Comprehensive Evaluation described in the solicitation to be performed.

\subsubsection{Comprehensive Evaluation}

The Technical Evaluation Criteria were divided into two major categories: (1) the Demonstration Project Factors were used to assess the technical and environmental merit of the project and the technical and management approaches to execute the project, and (2) the Commercialization Factors were used to assess the potential of the proposed technology to significantly improve environmental performance and efficiency in new or existing facilities and to achieve wide commercial acceptance.

The Cost and Finance Evaluation criteria were used to determine the business performance potential and commitment of the proposer.

The PON provided that the Cost Estimate would be evaluated to determine the reasonableness of the proposed cost. Proposers were advised that the cost and Finance Evaluation Criteria were of least importance to the selection, and that successful proposers would be required to submit a more detailed cost estimate after selection and before award. proposers were cautioned that if the total project cost estimate after selection was greater than the amount specified in the proposal, DOE would be under no obligation to increase the amount of funding above that which was requested in the proposal.

\subsubsection{Program Policy Factors}

The PON advised proposers that the following Program Policy Factors would be considered by the source selection official to select a range of projects that would best serve program objectives : 
(a) The desirability of selecting projects that collectively represent a diversity of methods, technical approaches, and applications.

(b) The desirability of selecting projects that collectively utilize a broad range of U.S. coals and are in locations which represent a diversity of environmental, health, safety, and socioeconomic regulatory, and climatic conditions.

The word "collectively", as used in the foregoing program policy factors, was defined to include projects selected in this solicitation and prior CCT solicitations, as well as other ongoing demonstrations in the United States.

\subsubsection{Other Considerations}

The PON provided that in making selections, DOE would consider giving preference to projects located in states for which the rate-making bodies of those states treat the CCT the same as pollution control projects or technologies. This consideration could be used as a tie breaker if, after application of the evaluation criteria and the program policy factors, two projects receive identical evaluation scores and remain essentialiy equal in value. This consideration would not be applied if, in doing so, the regional geographic distribution of the projects selected would be altered significantly.

\subsubsection{National Environmental Policy Act Compliance}

As part of the evaluation and selection process, the CCT Program developed a procedure for compliance with the National Environmental Policy Act (NEPA), the Council on Environmental Quality (CEQ) NEPA regulations (40 CFR Parts 1500-1508), and the DOE guidelines for compliance with NEPA (52 FR 47662, December 15, 1987). DOE NEPA regulations replacing the DOE guidelines were published in the Federal Register on April 24, 1992 (57 FR 15122) and are now codified at 10 CFR Part 1021. This procedure included the publication and consideration of a publicly available Final Programmatic Environmental Impact Statement (DOE/EIS-0146), issued in November 1989, and the preparation of confidential, preselection project-specific environmental reviews for internal DOE use. DOE also prepares publicly available sitespecific documents for each selected demonstration project as appropriate under NEPA.

\section{2 .8 Selection}

After considering the evaluation criteria, the program policy factors, and the NEPA strategy as stated in the PON, the Source selection official selected five projects as best furthering the 
objectives of the CCT-V PON. These selections were announced on May 4, 1993.

\subsection{TECHNICAL FEATURES}

\subsection{PROJECT DESCRIPTION}

The Four Rivers Energy Modernization Project provides for the design, construction and operation of a 95-MWe gross equivalent second generation PCFB cogeneration facility. A process schematic is shown in Figure 2 .

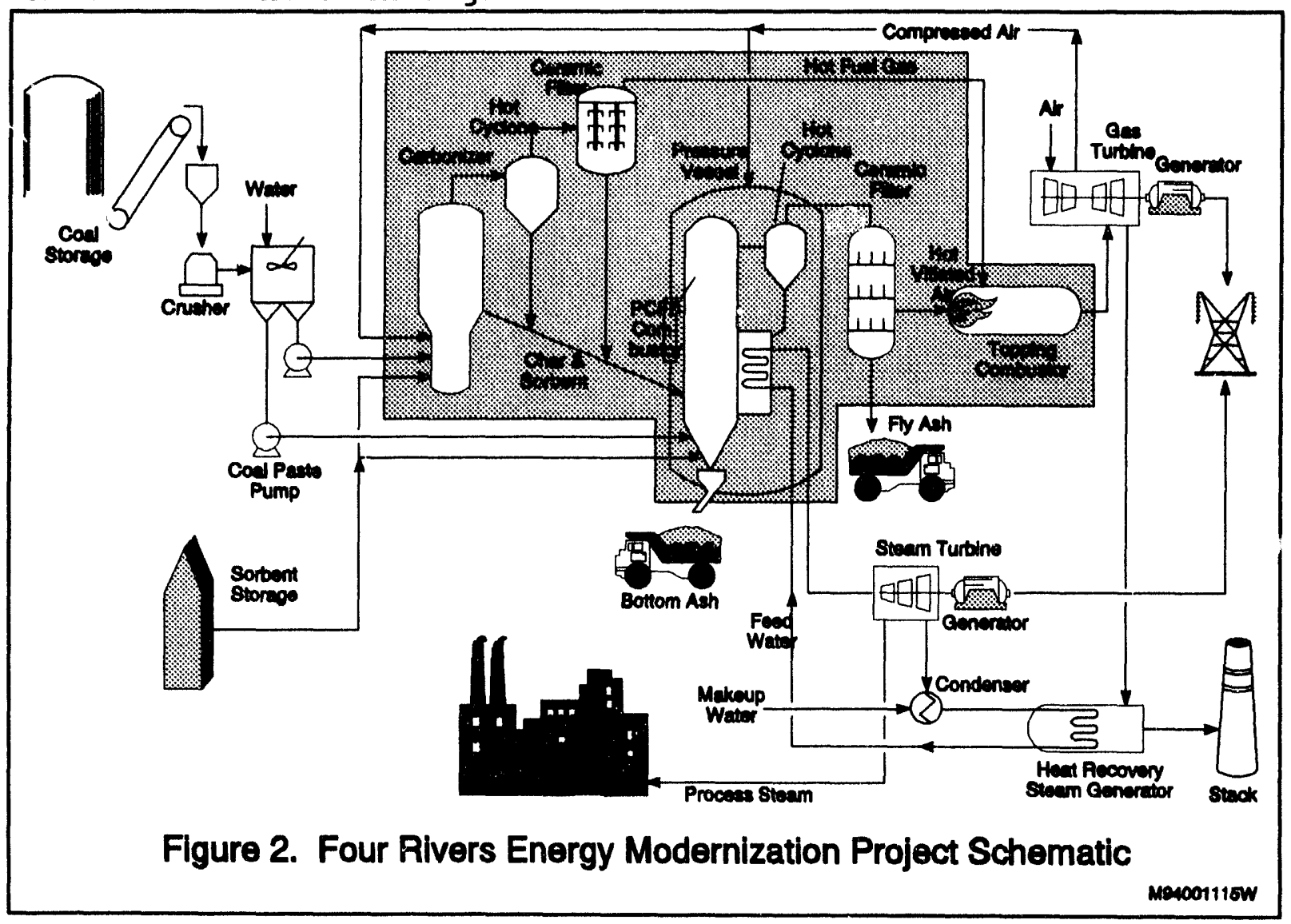

The Project is to be located on 17 acres adjacent to an existing APCI chemicals manufacturing facility near Calvert City, Marshall County, Kentucky. Figure 3 shows an artist's conception of the Project facility. The demonstration plant will produce approximately 70 MWe of electrical power for the utility grid and an average of 310,000 pounds per hour of process steam for the chemicals manufacturing facility. If all the steam were converted to electricity, the total power output would be equivalent to $95 \mathrm{MWe}$. The Project, including the demonstration phase, will last 80 months at a total cost of $\$ 360,707,500$. DOE's share of the project cost will be 39.5 percent, or $\$ 142,460,000$. 


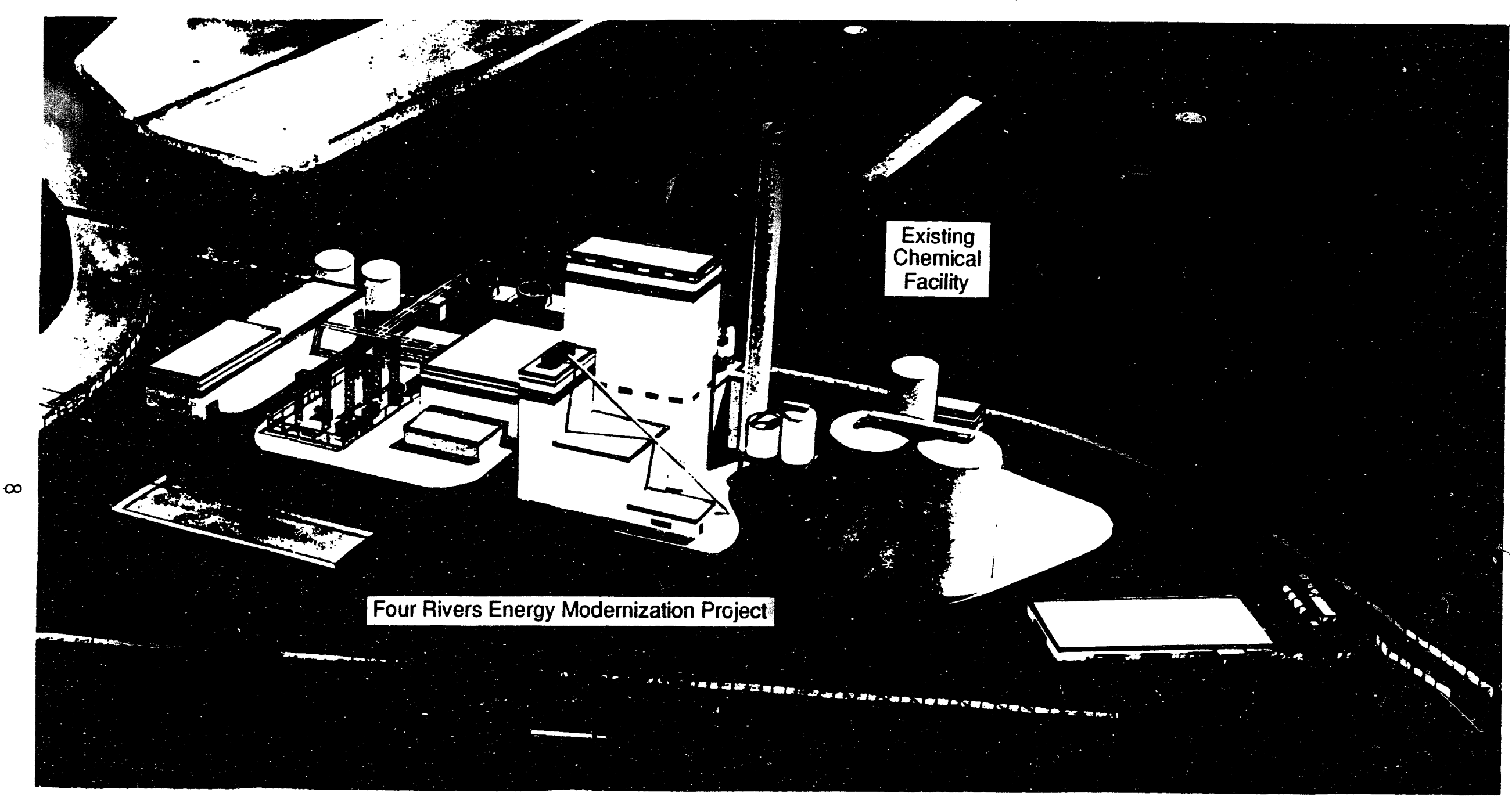

Figure 3. Artist Conception of Project 
The objective of the Profect is to demonstrate that a second generation PCFB cogeneration facility, based on technology being supplied by FWEC, Westinghouse, and LLB, can effectively burn a broad range of U.S. coals in an environmentally responsible manner. The Project will utilize technologies that, when integrated, are capable of achleving an efficiency of 45 percent, providing significant energy cost savings, while reducing sulfur dioxide and nitrogen oxide emissions as compared to conventional coal-fired bollers. The specific goal is to demonstrate that the technology is ready for commercialization. The integrated performance to be demonstrated will involve all of the process systems, including coal preparation and feed, sorbent feed, carbonizer, char transfer, pressurized circulating fluidized-bed combustor, carbonizer and combustor hot-gas filtration, carbonizer and combustor alkali removal, topping combustor, gas turbine-generator, heat recovery steam generator (HRSG), steam turbine-generator, and balance-of-plant systems.

The facility will use approximately 870 tons per day of 2.4-to3.5-percent-sulfur coal. The coal will be locally mined Western Kentucky and Southern Illinois bituminous coal, providing a continuing outlet for local high-sulfur coals, which otherwise could suffer a reduction in demand due to fuel switching to meet the requirements of the clean Air Act. In addition, about 170 tons per day of locally mined limestone will be used as a sulfur sorbent.

The project activities include engineering and design, permitting, procurement, construction, start-up, and operation. Project construction activity would average 250 workers and would peak at 450 workers. Long-term operation of the facility is expected to require approximately 50 employees. Using the Regional Input-Output Modeling System published by the Bureau of Economic Analysis, U.S. Department of Commerce, in May 1992, DOE estimates that there will be approximately 2,600 jobs created as a direct-effect of the construction activity and an average of 275 long-term jobs created as a direct-effect of the operation of this facility. It is estimated that there will be a total of more than $\$ 40$ million of additional spending associated locally with the long-term operation of the facility.

During the 30-month demonstration phase, the second generation PCFB plant will be operated in a commercial mode. The requirement to provide a non-interruptable supply of steam to the chemicals manufacturing facility places a strong emphasis on system reliability and backup systems. This project represents a critical step in the commercialization of the technology by demonstrating its performance and by showing that key subsystems can be integrated into a power plant with high system efficiency, attractive system operating characteristics, and competitive capital and operating costs. 
Successful demonstration of this project will encourage electric utilities and industrial power producers to construct similar size or larger units and will foster the eventual wide-scale deployment of the technology. DOE believes that the profect team, consisting of FREP, APCI, FWEC, Westinghouse, and LLB, has the demonstrated commitment, ability, and experience to conduct this project and the commercialization effort.

\subsubsection{Project Summary}

Title:

Proposer:

Four Rivers Energy Modernization Project

Location:

Air Products and Chemicals, Inc.

APCI-owned site adjacent to an APCI chemicals manufacturing plant near Calvert City, Marshall County, Kentucky

Technology:

Second generation PCFB combined cycle cogenerating steam and electric power

Applications:

Utility and industrial electric power generation; cogeneration; repowering of steam turbines; and repowering of conventional pulverized coal power plants and oil- or natural gas-fired power plants

Type of Coal Used:

Western Kentucky and Southern Illinois bituminous

Products :

Electric power, steam

Project Size:

95 MWe, gross equivalent (approximately 70 MWe electric and 310,000 pound per hour steam, average), 870 tons of coal per day

Profect Start Date: August 1994

Project End Date: April 2001

\subsubsection{Project Sponsorship and Cost}

Project Sponsor: $\quad$ Four Rivers Energy Partners, L.P.

Project Co-Funder: U.S. DOE

Estimated Project Cost: $\$ 360,707,500$

Cost Distribution:

Participant Share, 60.5 percent DOE Share, 39.5 percent 


\subsection{SECOND GENERATION PCFB PROCESS}

\subsubsection{Overview of Process Development}

PCFB systems combine PFBC and atmospheric circulating fluidized bed (ACFB) technologies. ACFB experience has shown that circulating bed performance (higher combustion efficiencies, lower nitrogen oxide emissions, and lower sulfur dioxide emissions at lower calcium-to-sulfur ratios; can be superior to bubbling bed performance. Investigation of ACFB combuscion began in the early 1970 's. Since that time, ACFB's have been widely accepted and deployed.

Development work on PCFB systems began in the late 1980 's. In 1989, Ahlstrom of Finland initiated operation of a 10 megawatt thermal (MWt) PCFB testing facility. This facility is providing data to support a first generation PCFB Demonstration Project, a CCT-III project, which will use the PCFB technology developed by Pyropower Corporation of San Diego California.

In late 1987, Deutsche Babcock Energie-und Umwelttechnik AG, now part of LLB, began operation of a 15 MWt test facility in Germany. This facility has completed over 2000 hours of operation in a PFBC (bubbling) mode and over 600 hours in the PCFB (circulating) mode. The PCFB combustor and major components, including a coal slurry feed system and hot gas filtration system were tested at this facility. These PCFB components are very similar to those proposed for the Four Rivers Energy Modernization Project.

Under a separate $\$ 37$ million research and development (R\&D) contract with DOE, Foster Wheeler Development Corporation (FWDC) has been developing a second generation PCFB system. A $1.1 \mathrm{MWe}$ equivalent pilot pant has been constructed in Livingston, New Jersey. During phase 2 of this R\&D effort, both the carbonizer and the PCFB combustor are being tested independently. Under Phase 3, scheduled to begin operation in late-1994, the carbonizer, PCFB combustor, and high temperature gas cleanup (HTGC) systems will be operated simultaneously.

Westinghouse is activel $y$ developing several key components of the second generation PCFB system. As a subcontractor to FWDC under the DOE R\&D contract, Westinghouse has been conducting multiannular swirl burner (MASB) testing at the University of Tennessee Space Institute since 1990. These tests have been dedicated to the development of a topping combustor firing lowBTU gas from the carbonizer. In addition, the carbonizer filter technology proposed by Westinghouse is based on Westinghouse's design and operation of similar ceramic filter systems and development programs, including test units at FWDC's pilot plant. Westinghouse has also developed the carbonizer and combustor alkali removal systems. 
Under a different Cooperative Agreement with DOE, Southern Company Services will build a 8 MWe equivalent facility which incorporates the FWDC second generation PCFB process. The Power Systems Development Facility (PSDF), at Wilsonville, Alabama, will have an operating carbonizer, PCFB combustor, multiple gas cleanup devices, a topping combustor, and a small gas turbine. The PSDF will test an integrated system at significant scale-up in order to address important commercial plant issues. PSDF operation will provide confirmation of the Project's design principles used in scaling from the pilot plant facilities to the Four Rivers Energy Modernization Project.

In accordance with PON guidelines for the CCT-V solicitation, Project Specific Design Activities (PSDA) were proposed. The PSDA are intended to address issues that are unique to the proposed facility including the MASB firing temperature, slurry feed composition, design and operating criteria for the combustor and carbonizer, and ceramic filter design and operating parameters. These issues would not otherwise be addressed in any current programs.

\subsubsection{Process Description}

The Four Rivers Energy Modernization Project will employ the process as shown in Figure 2. Coal is fed as a slurry to a pressurized carbonizer that produces a low-BTU fuel gas and char. Limestone or dolomite is fed to the carbonizer to catalytically enhance the cracking of tars and capture the sulfur component of coal.

After the fuel gas is cleaned of particulates and alkali vapors by a cyclone, ceramic filter, and alkali removal systems, it is burned in a topping combustor to produce the energy required to drive a gas turbine. The gas turbine drives a generator and a compressor that delivers air to the carbonizer and the PCFB combustor.

The particles elutriated from the carbonizer are captured in a cyclone and ceramic filter. This material along with bed material drained from the carbonizer and fresh coal slurry and limestone or dolomite is fed into the PCFB combustor. The coal and the carbonizer char are burned in the PCFB combustor, which is a water-wall vessel with an INTREX ${ }^{\mathrm{TM}}$ integrated heat exchanger unit. Coal sulfur released in the combustor is captured by the sorbent. NOx (mixed oxides of nitrogen) emissions are reduced by a combination of staged colnbustion and temperature control. The INTREX ${ }^{T M}$ integrated heat exchanger cools circulating bed ash in a series of bubbling bed chambers. Typical of circulating, fluidized-bed combustors, bed temperature is controlled by recirculating this cooled ash. 
The vitiated air (flue gas) from the PCFB combustor is also cleaned using a cyclone, ceramic filter, and alkali removal system. This air combines with fuel gas from the carbonizer in the MASB within the topping combustor housing. The MASB achieves complete combustion of the low-Btu fuel gas while maintaining low NOx emissions. The vitiated air is raised to about $1975{ }^{\circ} \mathrm{F}$ in the topping combustor. This hot vitiated air enters the expander section of the gas turbine.

A Westinghouse Model 251 is the anticipated gas turbine. This model will need some modifications to meet the design requirements: to extract high pressure air for the carbonizer and PCFB combustor, to replace the internal combustors with the external topping combustor, and to duct the hot gas exiting the topping combustor into the expander section of the turbine.

Steam generated in the HRSG downstream of the gas turbine, the INTREX ${ }^{\text {TM }}$ integrated heat exchanger, and the PCFB combustor drives the steam turbine generator that produces the balance of electric power delivered by the plant. An average of 310,000 pounds per hour of steam is extracted from the steam turbine and sent to the adjacent chemicals manufacturing facility.

\section{3 GENERAL FEATURES OF PROJECT}

\subsubsection{Evaluation of Developmental Risk}

Subsequent to selection and as a part of the fact-finding process, DOE performed a detailed evaluation of the Four Rivers Energy Modernization Project and determined it to be reasonable and appropriate. The evaluation focused on the project's technical, schedule, and cost risks. A team of experts both from within DOE and available under contract contributed to the evaluation. The data base for the evaluation included Participant-furnished documentation and fact-finding discussions with the Participant.

DOE recognizes that demonstrating the commercial readiness of new technologies inherently carries a certain amount of risk. Careful assessment of the risks associated with this project, coupled with the potential benefits of the technology, lead DOE to conclude that those risks are acceptable and worth taking.

The project uses new technologies in the following systems: the carbonizer, char transfer, PCFB boiler, carbonizer and combustor hot gas filtration, alkali removal, and topping combustor. Consequently, there is a higher risk associated with these process areas than if commercially available systems were used. The degree of technical risk is mitigated by the demonstrated abilities and experience of the project Team, the strength of the development effort, as described in Section 3.2.1, and the planned pilot plant testing and PSDA. Therefore, the project's 
overall design base and technical risk are considered to be reasonable.

The 80-month schedule allows sufficient time for design, construction, and operation of the demonstration project. The project schedule is presented in section 6.2. The first budget period allows for completion of a definitive cost estimate and completion of NEPA requirements. This determination is premised on the current assumption that an Environmental Assessment is the appropriate level of NEPA documentation. Should DOE determine that an Environmental Impact statement is required, the schedule may change. The planned 31-month design phase will provide sufficient time to complete project engineering and design. Phase 2, construction, is scheduled to begin 14 months before the completion of Phase 1 to a? low for early procurement of long-lead time equipment, such as the gas turbine. Finally, the planned 30-month operation phase will allow for demonstration of process performance, system availability, and reliability, in order to provide a technizal, economic, and environmental evaluation of second generation PCFB power plants.

The cost estimate, further evaluated during the fact-finding process, was prepared considering the estimates prepared by APCI and the project team. Preliminary engineering specifications were developed for all purchased equipment items based on conceptual versions of the process flow diagrams and heat and material balances. Budgetary quotes were solicited for all major equipment items. A high percentage of equipment costs were supported by vendor quotes or budgetary quotes. In-house data were used to estimate the few remaining equipment items. Estimated construction and operating costs were based upon APCI's recent experience with cogeneration facilities and numerous other industrial gas, chemicals, and power plants. These estimating methods are very reasonable given the extensive experience of the project team. A financial risk analysis program was used by DOE to evaluate the risk in the project cost estimate. Based on a review and evaluation of the information provided, DOE concluded that the estimated cost is reasonable.

\subsubsection{Similarity of Project to Other Demonstration and Commercial Efforts}

The Four Rivers Energy Modernization Project is one of four PFBC projects being demonstrated in the CCT Program. The Tidd PFBC Demonstration Project and the PFBC Utility Demonstration Project are based on $A B B$ Carbon $A B$ 's first generation bubbling-bed PFBC technology, which is licensed to Babcock \& Wilcox for U.S. sales. The PCFB Repowering Project uses Pyropower's first generation, pressurized circulating fluidized-bed combustion technology to repower an existing steam turbine at Midwest Power Company's Des Moines Energy Center. The Four Rivers Energy Modernization 
Project is unique in that it will be the first large-scale, fully-integrated second generation PCFB system.

\subsubsection{Technical Feasibility}

As discussed in section 3.3.1, DOE recognizes that technical uncertainties exist in the proposed project, especially with regard to scale up of new technologies from pilot plant data. Areas of moderate-to-medium technical risk are coal slurry feeding, carbonizer, char transfer, PCFB combustor, topping combustor, high temperature gas filtration, and plant integration. Scale-up from the pilot plant units is facilitated by several factors. As discussed in section 3.2.1, there is a solid history of PFBC development activities. Planned development and testing programs under other DOE contracts and PSDA under the Cooperative Agreement address each of the areas of moderate-to-medium risk and will further mitigate the technical risk. Overall, the project is considered to be technically feasible.

\subsubsection{Resource Availability}

All of the resources required for the project are available. APCI owns the proposed site and has committed to its share of the project financing through each budget period. Essential infrastructure services are available, including water, natural gas, rail and highway access, electric service, and sanitary waste disposal.

\subsubsection{Relationship Between Project Size and Projected Scale of Commercial Facility}

The commercial embodiments of the Four Rivers Energy Modernization Project include industrial-and utility-scale cogeneration, repowering, and new electric generating facilities. The project size provides for demonstration of a large, industrial-scale second generation PCFB system, which incorporates all the features of the commercial technology. The demonstration facility will produce an average 310,000 pounds per hour of steam for the adjacent chemicals plant and approximately 70 MWe for export to the utility power grid. The equivalent power output is 95 MWe on an all-electric basis. The Project will utilize the latest technical innovations for all key components. Future commercial facilities would benefit from additional technical advances, particularly in higher firing temperatures for gas turbines and improved steam cycles. Technical, economic, and environmental data from the project will be directly applicable to commercial projects. 
For utilities and industries requiring small increments of power (40 to 100 MWe) the demonstration unit size would be essentially replicated. Larger utility-scale units, on the order of 300 MWe, would be built by moderate $(3: 1)$ scaling of the PCFB module. This size range is compatible with essentially all commercially available advanced gas turbines. The size of the PCFB module is effectively limited by the largest available gas turbines and pressure vessel size. Future, larger utility power plants could be based on incremental scaling of the 300 MWe unit or replication of PCFB modules, with economics of scale achieved in the steam cycle and other balance of plant systems.

\subsubsection{Role of Project in Achleving Commercial Feasibility of Technology}

The demcnstration plant will provide utilities and other power generators with design, construction, and operating data on which to base future decisions regarding new power generation options. A demonstration plant such as this is an essential next step in commercializing the technology for industrial and utility cogeneration and power generation applications.

Verification of the commercial feasibility of the second generation PCFB technology is expected to be accomplished during the planned 30-month test program to begin in 1998. Once the demonstration program is completed, the plant will continue to be operated commercially, establishing long-term system reliability, economics, and environmental performance.

During and following a successful demonstration period, the Second Generation technology will be offered to utility and industrial users. The technology offers several advantages which contribute to its marketability:

- It will be demonstrated at a commercial size.

- It has higher efficiencies than conventional pulverized coal systems and most other competing technologies.

- It can be used to repower existing pulverized coal power plants as well as oil-or natural gas-fired power plants and can be used in ccgeneration applications.

- It is projected to have lower capital and operating costs than competinig pulverized coal systems.

- It has the capability of using all U.S. coals and of minimizing water usage.

- It has the environmental flexibility to meet current and future environmental constraints. 
- The infrastructure needed to commercialize the technology exists on a nationwide basis.

- The potential market for the technology is large and market penetration is likely to be high if the Participant's economic, efficiency, reliability, and environmental targets are met.

It offers high process efficiency and reduced space requirements per unit of energy generated.

The project team of APCI, FWEC, LLB, and Westinghouse will be in an excejlent position to commercialize the technology to be demonstrated. The technology's advantages of modularity, high efficiency, environmental controllability, and reduced land and natural resource needs will enhance the potential for the technology to become a strong contender for widespread application for meeting future U.S. energy needs.

\subsubsection{Agreement with an Electric Utility}

An agreement with an electric utility is necessary in order for the project to be economically viable. The Participant provided DOE documentation indicating good faith negotiations are ongoing with an electric utility. These negotiations are leading to arrangements that make the project economical viable. It is expected that an agreement with an electric utility will be in place on or before December 31,1994 .

Prior to the Participant obtaining an agreement with an electric utility, DOE anticipates that $\$ 3.7$ million of DOE funds $(\$ 7.8$ million total project) will be expended. These funds represent approximately 3 percent of the total DOE funding. If an agreement with an electric utility is not in place by the end of calendar 1994, DOE has the unilateral right to terminate the Cooperative Agreement or to withhold all further payments until an agreement has been obtained with an electric utility. This Cooperative Agreement provision limits the expenditure of federal funds to an amount considered reasonable and an amount needed to insure that the project goes forward for a length of time prudent to negotiate an agreement with an electric utility. DOE has fully protected itself from incurring continual costs if the agreement with an electric utility can not be negotiated in a reasonable length of time.

Regardless of whether or not an agreement with an electric utility is negotiated, the following benefits will accrue from the planned initial project activities:

- Detailed cost estimate: This will provide an important data point to determine how acceptable this particular clean coal technology is from a capital cost perspective. 
- Environmental Information: A comprehensive analysis of the environmental impacts this technology might cause will be public information which users of this technology can share with communities that host future second generation PFBC plants.

- Upgraded capital and operating cost estimates: A portion of the Project Specific Development Activities (PSDA's) will be done by December 1994 , generating additional design data for the technology vendors. This additional information in the design data base will produce better capital and operating costs estimates for future plants, increasing the likelihood of commercial acceptance. These PSDA's will create specific information on the environmental emissions associated with Kentucky coal in a second generation PFBC and whether there are any equipment changes necessary to the plant configuration.

- Updated plant performance estimates: Preliminary designs will be completed which will be releasable in a p:blic Design Report, showing how a 95 MWe power plant based on this technology needs to be configured.

- Site-transferable design information: The conceptual design activities that will be done are essentially site neutral. They have value if the project would be moved to an alternate location.

DOE believes that this information directly relates to the commercial acceptance of second generation PFBC technology and is worth $\$ 3.7$ million. DOE has invested.almost $\$ 100$ million in this technology through a) its research and development contracts with the Foster Wheeler Corporation, and b) its Cooperative Agreement with the southern Company to conduct the first integration testing of an 8 MWe unit. The expenditure of DOE funds to conduct the initial activities of the project prior to an agreement with an electric utility, provides significant benefits to the Government and the industrial and utility market sectors in furthering this technology.

\subsection{ENVIRONMENTAL CONSIDERATIONS}

The overall strategy for compliance with NEPA, cited in section 2.2.7, contains three major elements: a Programmatic Environmental Impact statement (PEIS); a preselection, projectspecific environmental analysis; and a post-selection, sitespecific environmental analysis. To satisfy the first element, DOE issued the final PEIS to the public in November 1989

(DOE/EIS-0146). In the PEIS, results derived from the Regional Emissions Database and Evaluation System (REDES) were used to estimate the environmental impacts that might occur in 2010 if 
each technology were to reach full commercialization, capturing 100 percent of its applicable market. The environmental impacts were compared to the no-action alternative, which assumed continued use of conventional coal technologies through 2010, with new plants using conventional flue gas desulfurization to meet New Source Performance Standards (NSFS).

Projected environmental impacts in 2010 from maximum commercialization of the PCFB technology are presented in Table 1 for the entire nation as well as regional areas. Negative percentages indicate decreases in emissions or waste quantities in 2010 as compared to the no-action alternative. Conversely, positive percentages indicate increases in emissions or waste quantities. These computer-derived results should be regarded as approximations of actual impacts.

As shown in Table 1, commercialization of the PCFR technology would provide sulfur dioxide, nitrogen oxides, and carbon dioxide emission reductions, with the largest reductions occurring in the eastern quadrants. The Northwest quadrant would be least affected by air emission reductions and shows an increase in solid waste production. On a national basis, solid waste production shows a slight decrease. The quadrants used in the REDES study are depicted in Figure 1.

Table 1. Projected Environmental Impacts in 2010, Pressurized Circulating Fluidized-Bed (Percentage Change Over NoAction Alternative)

\begin{tabular}{ccccc}
\hline Region & $\begin{array}{c}\text { Sulfur } \\
\text { Dioxides }\end{array}$ & $\begin{array}{c}\text { Nitrogen } \\
\text { Oxides }\end{array}$ & $\begin{array}{c}\text { Carbon } \\
\text { Dioxide }\end{array}$ & $\begin{array}{c}\text { Solid } \\
\text { Wastes }\end{array}$ \\
\hline National & -488 & -178 & -88 & -48 \\
Northeast & -608 & -228 & -68 & -58 \\
Southeast & -608 & -248 & -68 & -128 \\
Northwest & -98 & -68 & -58 & +318 \\
Southwest & -328 & -138 & -108 & -158 \\
\hline
\end{tabular}

Source: Programmatic Environmental Impact statement (DOE/EIS-0146), November 1989 .

Since the sorbent in the circulating fluidized-bed captures most of the sulfur during the combustion process, the need for expensive, downstream sulfur control equipment is greatly reduced or completely eliminated. Reductions in nitrogen oxides result from lower operating temperatures. The sulfur dioxide removal rate is expected to be greater than 95 percent, and the reduction rate for the oxides of nitrogen is expected to be greater than 75 percent. Carbon dioxide emission reductions would result primarily from the improved efficiencies of PCFB technology over 
conventional coal-fired technologies. The high-temperature gas filters reduce particulates to levels compatible with the gas turbine. This particulate level is lower than that obtained by the use of conventional pollution control equipment. Therefore, a significant reduction from baseline particulate emissions would be expected.

Emissions of trace substances associated with a PCFB burning coal are expected to be lower than the emission levels of current utility power plant technology. It is anticipated that, since most of the air toxics are associated with particulate emissions, the highly-efficient HTGC system will capture most of these potentiai pollutants. It is further anticipated that the PCFB technology will provide a high degree of destruction of the small amounts of organic compounds due to the residence time in the combustor. The ability of the PCFB technology to reduce or control these emissions will be monitored during the demonstrations.

One of the major environmental trade-offs associated with reducing atmospheric emissions by using CCT's is the generation of solid wastes that require disposal. While PCFB combustors use more sorbent to remove sulfur dioxide than the conventional systems, they would produce less solid waste because of their substantially higher energy efficiency. PCFB technology produces a dry solid waste which is easier to handle and dispose of than wet scrubber sludges and is suitable either for beneficial reuse or for disposal in a landfill.

Water consumption for PCFB combustors is not expected to be significantly different than for the no-action alternative. While conventional technologies consume large quantities of water for boiler water makeup (steam generation), boiler blowdown and cooling, coal cleaning, and wet scrubbers, PCFB facilities are expected to use less water. PCFB facilities would not require coal cleaning processes or wet scrubbers and would be expected to require less boiler water makeup because of their more efficient steam generation.

The second element of DOE's NEPA strategy for the CCT Program involved preparation of a preselection environmental review based on project-specific environmental data and analyses that offerors supplied as part of their proposals. The review summarized the strengths and weaknesses of each proposal against the environmental evaluation criteria. It included, to the extent possible, a discussion of alternative sites and processes reasonably avallable to the offeror, practical mitigating measures such as the options for controlling discharges and for management of solid and liquid wastes, impacts of each proposed demonstration on the local environment, and a list of required permits. Finally, the risks and impacts of each proposed project were 
assessed. This analysis was provided for the Source selection Official's use before the selection of projects for negotiation.

As the final element of the NEPA strategy, the participant must submit to the DOE the environmental information specified in Appendix $J$ of the PON. This detailed site- and project-specific information will be used as the basis for the site-specific NEPA documents to be prepared by DOE. These documents will be prepared in full compliance with NEPA and the CEQ and the DOE regulations for compliance with NEPA, and will be completed and approved before Federal funds are provided for any activity that would limit the cholce of reasonable alternatives to the proposed action or have an adverse environmental impact. The DOE has not yet made a final determination of the appropriate level of NEPA documentation for this project.

In addition to the NEPA requirements outlined above, the Participant must prepare and submit an Environmental Monitoring Plan (EMP) for the project following the guidelines provided in Appendix $\mathbf{N}$ of the PON. The purpose of the EMP is to ensure that sufficient technology, project, and site environmental data are collected to provide health, safety, and environmental information for use in subsequent commercial applications of the technology.

\subsection{PROJECT MANAGEMENT}

\subsection{OVERVIEW OF MANAGEMENT ORGANIZATION}

APCI has formed a project company named Four Rivers Energy Partners, L.P., (FREP) a Delaware corporation with of $f$ ices in Allentown, Pennsylvania. The initial partners are Four Rivers Energy Partners, Inc. $(18$ general partner) and APCI (998 limited partner). A chart showing the relationship of FREP with APCI and the other team members is provided in Figure 4. APCI will execute a corporate guaranty that includes financing, performance, indemnification, and conditional repayment (see section 6.3) if FREP fails to comply with these requirements of the Cooperative Agreement.

As the signatory to the Cnoperative Agreement, FREP will be responsible for all aspect; of the project. FREP will manage the project through a Project Manager, who will be assisted by a team of technical and managerial personnel. On behalf of FREP, APCI will act as the turnkey contractor for the entire project. APCI will contract with the technology suppliers for the various plant systems. FWEC will provide turnkey engineering, procurement, and construction services for the PCFB Island which includes the second generation PCFB combustor, carbonizer and HRSG. LLB will provide process engineering services, the PCFB combustor filtration sy tem, the slurry feed system, and the ash removal 


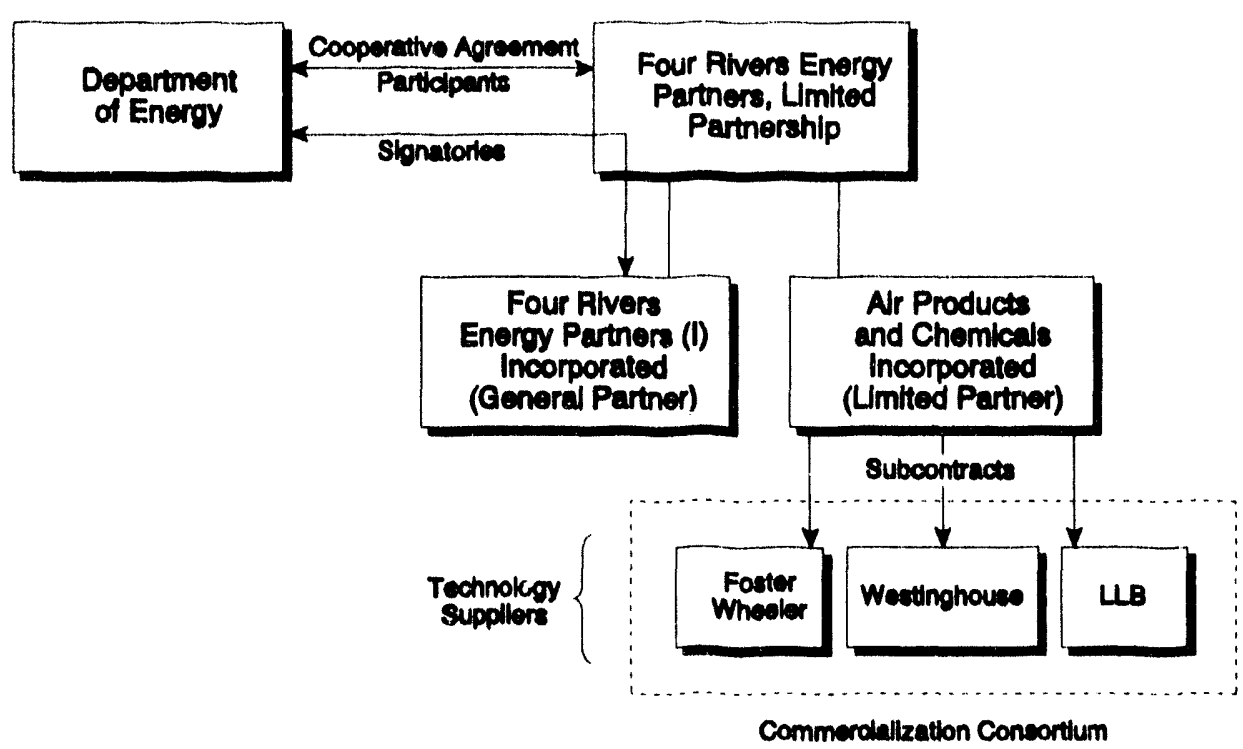

Figure 4. Four Rivers Energy Modernization Project Organization

1900000

systems. Westinghouse will supply the topping combustor, gas turbine, carbonizer particulate filtration system, and alkali removal systems.

\subsection{IDENTIFICATION OF RESPECTIVE ROLES AND RESPONSIBILITIES}

\section{2 .1 DOE}

DOE will be responsible for monitoring all aspects of the profect and for granting or denying approvals required by tie cooperative Agreement. A DOE Project Manager will be designated by the DOE Contracting officer to act as a Contracting officer's

Representative. The Project Manager will be the primary point of contact for the project and will be responsible for DOE management of the project.

\subsubsection{Participant}

FREP, as the Participant, will be responsible for all aspects of the project, including design, permitting, construction, operation, data collection, and reporting. FREP will utilize the services of APCI for the turnkey engineering design, procurement, construction, and operation of the facility. FREP will designate a full time Project Manager, who will be responsible for all technical and administrative activities to be performed under the Cooperative Agreement. The Project Manager will be the primary point of contact with DOE. 


\subsection{PROJECT IMPLEMENTATION AND CONTROL PROCEDURES}

FREP will prepare and maintain a Project Management plan that presents project procedures, controls, schedules, budgets, and other activities required to adequately manage the project. This document, which will be finalized shortly after execution of the Cooperative Agreement, will be used to implement and control project activities. Throughout the course of the project, reports dealing with the technical, management, cost, and environmental monitoring aspects of the project will be prepared and delivered to DOE.

\subsection{KEY AGREEMENTS IMPACTING DATA RIGHTS, PATENT WAIVERS, AND INFORMATION REPORTING}

With respect to data rights, DOE has negotiated terms and conditions that will generally provide for rights of access by DOE to all data generated or used in the course of or under the Cooperative Agreement by FREP and its subcontractors. DOE will have unlimited rights to data first produced in the performance of the Cooperative Agreement that is not proprietary nor protected Clean Coal Technology data, limited rights of access to proprietary data utilized in the course of the demonstration, and the right to use, but not disseminate for five years, protected Clean Coal Technology data. DOE will have the right to have relevant proprietary information delivered to it under suitable conditions of confidentiality.

With regard to patents, data and other intellectual property, the Participant has made a contractual commitment to exercise all commercially reasonable efforts to commercialize, or to assist others to commercialize, in the United States, the second generation PCFB technology as demonstrated in this project. To effect commercialization, the participant has also made a contractual commitment to flow down its commercialization obligation in all contracts with suppliers of the technology to be demonstrated under this Cooperative Agreement.

The Participant has requested for itself and on behalf of its subcontractors who will participate in the demonstration program, a waiver of patent rights in any subject invention, i.e., any invention or discovery by any of them which is conceived or first actually reduced to practice in the course of or under the Cooperative Agreement. Favorable action is anticipated to be given to the Participant's Patent Waiver request considering the level of cost sharing, the commitment by its principal subcontractor to commercialization of the second generation PCFB technology, and agreement to repay up to the Government's contribution in accordance with the DOE guidelines. Any grant of a patent waiver will reserve to the Government a nonexclusive, nontransferable, and irrevocable paid-up license to practice or 
to have practiced any waived subject invention for or on behalf of the United States.

\subsection{PROCEDURES FOR COMMERCIALIZATION OF TECHNOLOGY}

Design, construction, and operation of the Four Rivers Energy Modernization Project are vital steps toward widespread commercial application of this process. It is essential that a demonstration of the technology be conducted to confirm operating characteristics, economics, reliability, availability, and environmental performance at a scale sufficient to illustrate commercial potential. The 30-month operational phase will provide an adequate period to verify the design parameters of the second generation PCFB technology and will form the basis for predicting the reliability and operability of the process under expected as well as extreme operating conditions. Sufficient operating experience will have been generated to allow industry to fully evaluate the viability and competitive position of this new technology. After the demonstration program is completed, the plant will continue to be operated commercially, establishing long-term system reliability, economics, and environmental performance.

During and following a successful demonstration period, the second generation PCFB technology will be offered to utility and industrial users. The project team anticipates a strong market for this technology in industrial generation or cogeneration, independent power (IP), and new and repowering utility power generation applications. FWEC, a well known designer and supplier to the energy industry, will have exclusive rights for the second generation PCFB technology in the U.S. market. For the non-utility market in the U.S., APCI is investigating partnership arrangements with FWEC for future plants. APCI is well suited to market this technology in the IP market through its existing Environmental and Energy Systems IP business development infrastructure. With regards to other technology vendors, Westinghouse will support FWEC and APCI in their commercialization efforts. FWEC, along with APCI and Westinghouse, intend to devote the necessary resources to make this demonstration, and the subsequent commercialization of the advanced PCFB technology, successful. Commercialization and licensing agreements between the technology vendors and APCI have been agreed to in principle, and are expected to be finalized over the next several months.

\subsection{PROJECT COST AND EVENT SCHEDULING}

\subsection{PROJECT BASELINE COSTS}

The estimated cost and the cost sharing for the work to be performed under the Cooperative Agreement are as shown below. 
Pre-award Cost

DOE Share

Participant Share

\begin{tabular}{lrr}
$\$$ & 588,300 & 39.58 \\
$\$ \quad 900,200$ & 60.58 \\
\hline$\$ 1,488,500$ & 100.08
\end{tabular}

Phase 1

DOE Share

Participant Share

$\$ 29,262,400$

49.88

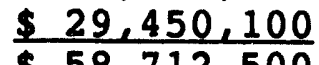

$\frac{50.28}{100.08}$

Phase 2

DOE Share

Participant share

$\$ 109,315,600$

$\$ 110,017,800$

$49.8 \%$

$\$ 219,333,400$

$\frac{50.28}{100.08}$

Phase 3

DOE Share

Participant Share

$\$ 3,293,700$

4.18

$\$ \frac{77,879,400}{\$ 81,173,100}$

$\frac{95.98}{100.08}$

\section{Total Estimated Project Cost}

DOE Share

Participant share
$\$ 142,460,000$

$\$ 218,247,500$ $\$ 360,707,500$ $\begin{array}{r}39.58 \\ 60.58 \\ \hline 100.08\end{array}$

Sequential budget period costs shall be shared by DOE and the Participant as shown below. At the beginning of each budget period, DOE intends to obligate sufficient funds to pay its share of the expenses for that period.

TOTAL ESTIMATED PROJECT COST

$\$ 360,707,500$

* Budget Period 1 DOE Share

Participant Share

$\$ 13,936,600$

$\$ 14,334,000$

Budget Period 2 DOE Share

Participünt Share

$\$ 128,523,400$

$\$ 203,913,500$

* Pre-award costs are included in Budget Period 1. 


\subsection{MILESTONE SCHEDULE}

The project is divided into three phases and is expected to take 80 months to complete. A project schedule is shown in Figure 5 .
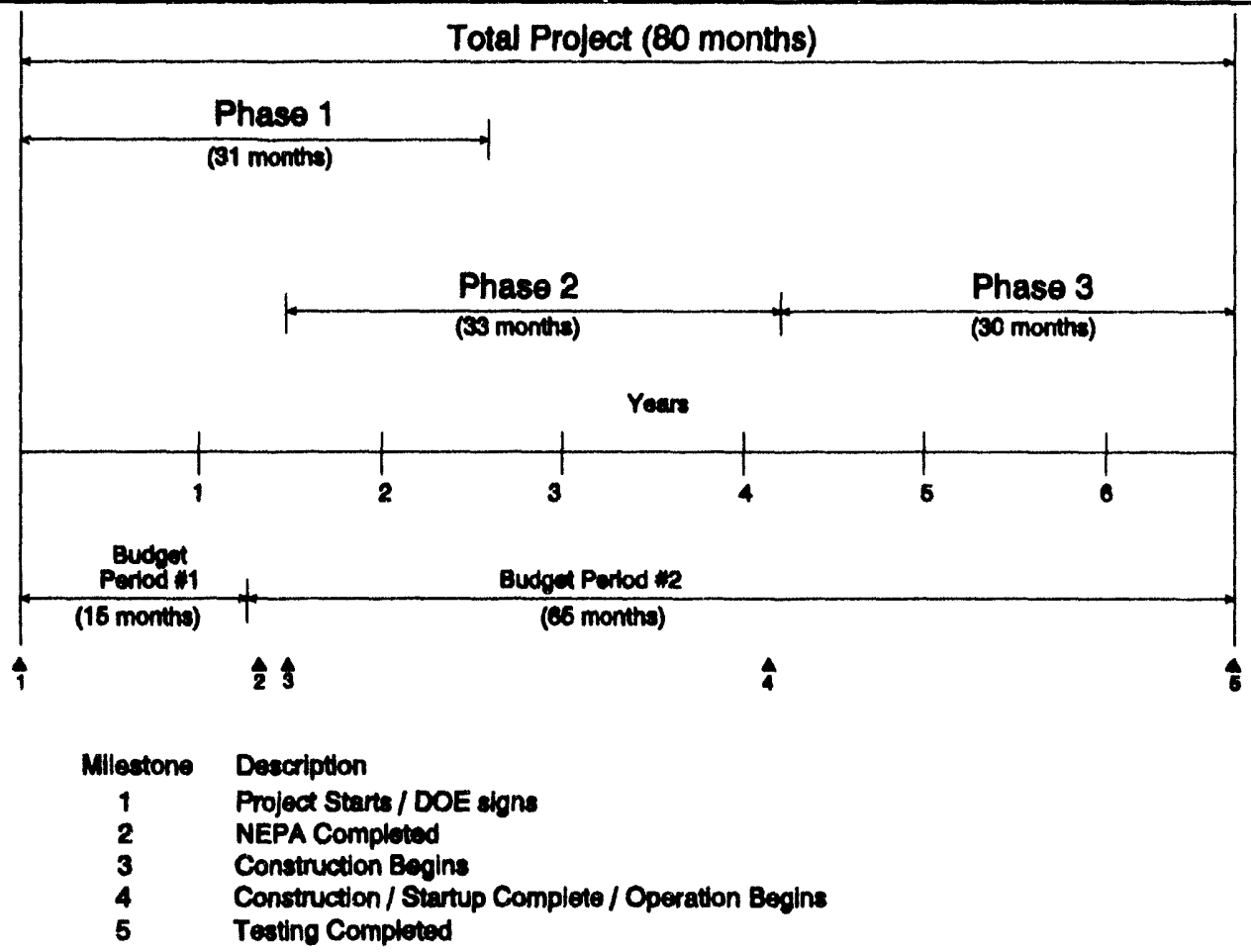

Figure 5. Four Rivers Energy Modernization Project

The phases and their expected durations are as shown below:

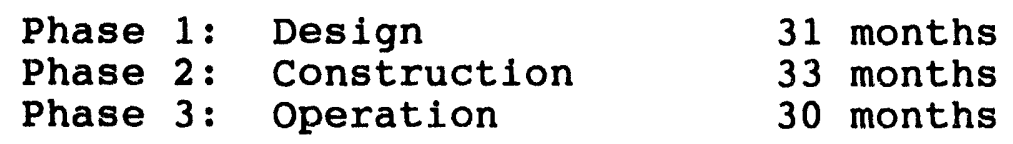

Phases 1 and 2 overlap by 14 months.

Budget periods are used to manage the financial risk of the project and to facilitate project decision making. The project is divided into two sequential budget periods as follows:

Budget Period $1--15$ months
Budget Period $2--65$ months

Construction is expected to be completed by August 1998, and the project is expected to be completed by April 2001. 
The first budget period will include permitting activities, support for NEPA activities, and development of the project management plan. This first budget period also includes project definition activities, pilot plant testing under the Project Specific Development Activities (PSDAs), design work, cost estimation of sufficient detall to secure approval of the Air Product's Board of Directors and finalization of commitments/agreements for Participant's total cost-sharing obligaticns under the Cooperative Agreement. All business and technical issues required to proceed into Budget Period 2 will be resolved during Budget Period 1.

Budget Period 2 includes the remainder of the design activities; procurement of all equipment items; construction including commissioning, start-up and acceptance of the plant; operation; testing; and data gathering.

\subsection{REPAYMENT AGREEMENT}

Based on DOE's recoupment policy as stated in section 7.7 of the PON, DOE is to recover an amount up to the Government's contribution to the project. Repayment to the Government shall be in accordance with the Repayment Agreement to be executed at the time of award of the Cooperative Agreement.

Repayment will be made by FWEC, through the FREP, based on a percentage of revenues received from equipment sales, equipment leases, and technology licensing. This applies in all cases except in the event the FREP unilaterally withdraws from the project for any reason other than FWEC withdrawing from the Project. In this case, FREP, using its own financial resources and backed by the APCI Corporate Guarantee, assumes all repayment obligations, based on the amount of equipment sales, equipment leases, and technology licensing revenues as reported by FWEC. 

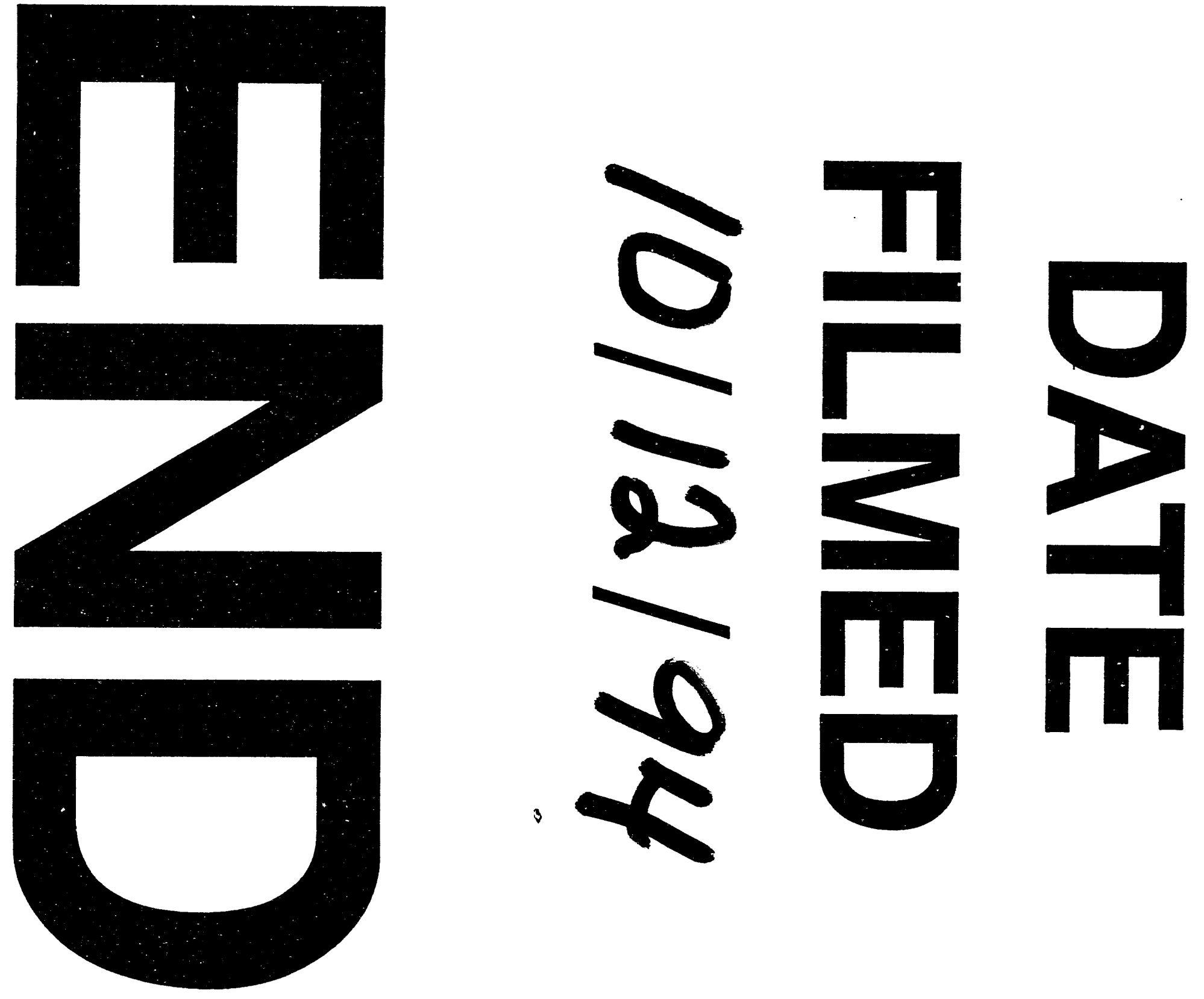
